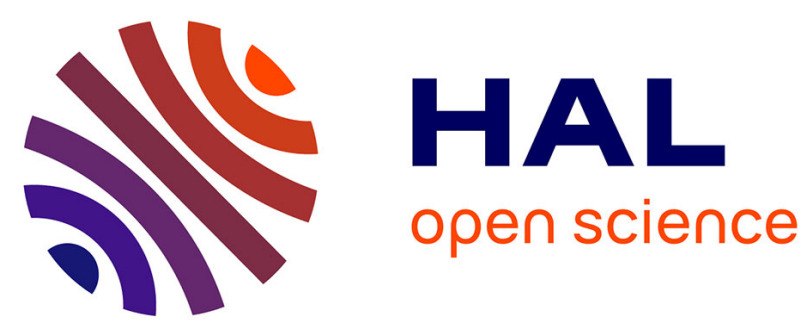

\title{
Cogs in the wheel or spanners in the works? A phenomenological approach to the diffculty and meaning of ethical work for financial controllers
}

\author{
François-Régis Puyou, Eric Faÿ
}

\section{- To cite this version:}

François-Régis Puyou, Eric Faÿ. Cogs in the wheel or spanners in the works? A phenomenological approach to the diffculty and meaning of ethical work for financial controllers. Journal of Business Ethics, 2015, 128 (4), pp.863-876. 10.1007/s10551-013-1986-6 . hal-01154529

HAL Id: hal-01154529

https://hal-audencia.archives-ouvertes.fr/hal-01154529

Submitted on 22 May 2015

HAL is a multi-disciplinary open access archive for the deposit and dissemination of scientific research documents, whether they are published or not. The documents may come from teaching and research institutions in France or abroad, or from public or private research centers.
L'archive ouverte pluridisciplinaire HAL, est destinée au dépôt et à la diffusion de documents scientifiques de niveau recherche, publiés ou non, émanant des établissements d'enseignement et de recherche français ou étrangers, des laboratoires publics ou privés. 
COGS IN THE WHEEL OR SPANNERS IN THE WORKS?

François-Régis Puyou, Audencia Nantes

Eric Faÿ, EM Lyon

EBEN 2012 Conference Barcelona

Paper accepted in the Journal of Business Ethics

COGS IN THE WHEEL OR SPANNERS IN THE WORKS?

A PHENOMENOLOGICAL APPROACH TO THE DIFFICULTY AND MEANING

OF ETHICAL WORK FOR FINANCIAL CONTROLLERS 


\section{Abstract:}

The aim of this paper is to propose a new perspective on the difficulty and meaning of ethical work for financial controllers. This is achieved by drawing on concepts from Michel Henry's phenomenology of life in the field of business ethics. The French philosopher Michel Henry (1922-2002) is distinguished by his identifying two modes of appearing: "intentionality" (appearing of the world through representations) and "affectivity" (appearing of life). Henry suggests that relying only on abstract representations constitutes a specific ideology that causes individuals at work to ignore the actual experience of being affected, and hinders the appearance of life to guide their actions, in turn hindering ethics. Empirical illustrations are provided by a case study that explores the practices of management accountants in a travel retail corporation. By observing the empirical practices of management accountants, a body of professionals whose role is largely dependent on Information Technology (IT), abstraction and technical expertise to trace organisational flows and transactions, we shed light on the difficult ethical issues associated with their role of surveillance and control of other managers' work. The case study illustrates a wide range of everyday working practices among management accountants. Some convey the impression that they lack empathy and consideration for other individuals, while others engage in close cooperation and ethical practices despite the constraining configuration of their role. A significant result of this research is that it illustrates and interprets, based on Henry's phenomenology, a wide range of working practices. Consistent with Henry, we argue that the source of business ethics lies beyond professional standards, codes and values.

Keywords: financial controllers; information technology; management accountants; Michel Henry; phenomenology; work ethics 


\section{Abbreviations:}

LSF: Loi de Sécurité Financière (French law to improve economic governance practices)

SOX: Sarbanes Oxley

SPP: Sales Per Passenger

IT: Information Technology 


\section{Prologue}

Airshop $^{1}$ is an airport retailer that owns concessions to sell luxury goods (alcohol, tobacco, perfume etc.) at the major French airports. On 23 May 2004, Terminal 2E of Paris Charles de Gaulle airport collapsed, killing four people. The accident caused little alarm and distress at Airshop's headquarters. Fortunately, no one from the company was injured, but Airshop had just lost one of its newest points of sale, and the terminal was closed for a long time. A few days later, the Airshop CFO explained that he had decided not to alter the forecasts submitted to the parent company days before the accident: Airshop's top executives considered that the event would have no impact on business. After all, it certainly would not dissuade tourists and businessmen from visiting Paris. There would be no sales at Terminal 2E but sales would continue at shops in other terminals. Customer flows would be distributed differently, which affected the allocation of local sales targets but not overall objectives. Airshop is very proud of its management accounting reporting system: at Airshop's headquarters, the company's entire business is reflected in the variations of the Sales Per Passenger (SPP) ratio, i.e. "sales divided by the number of travellers going through the terminals." The SPP ratio is calculated by product category, terminal, and passenger nationality and serves as a basis for calculating forecasts and targets, and explaining actual performance. It is used to compare past and present performance, set objectives, and estimate the impact of variations in exchange rates, customer mix, or sales force skills. The SPP offers a satisfactory view of Airshop's activities to executives and strongly justifies the decision not to adjust expectations following the collapse of the terminal. Airshop's leaders seemed to have no clear idea of the massive disruption caused by the accident for the operational staff on site, who had to reorganise the workforce entirely between sites, while facing unchanged objectives with fewer points of sale. The possible impact of the accident on the people working in airport shops had gone unnoticed by top management. 


\section{Introduction}

The growing reliance on Information Technology (IT) in organisations has dramatically transformed the experience of work for millions of employees worldwide. Software and hardware have been pivotal aids to individuals who engage in working relations. They abound with abstract representations of products, services, flows, people, etc. that exist only on screens and are arranged using cursors and pointers. A body of studies comments on the simplistic nature of "abstract" management based on technologies, which ignores the ambivalence of situations and the contextual character of measurement and knowledge. They allow managers to complete their tasks while eliminating the effort of face-to-face management (e.g. Sanders 1982; Townley 2002; Knights and O’Leary 2006; Hancock 2008). In a similar vein, it has been shown that the use of IT interfaces immediately signals to users what is to be considered important (Introna and Ihlarco, 2004). The difficult task of giving meaning collectively is massively delegated to technologies for "packaging data" that simplify reality (Boland, 1987, p. 372). The use of IT in firm management thus influences the types of working relations between co-workers. It is, however, doubtful that the transformations induced by IT and abstractions have univocal effects on ethics within organisations. This article aims to understand the extent to which roles such as financial controller and management accountant, ${ }^{2}$ which are largely dependent on IT and abstractions, mould an ideological vision of other co-workers as a means to achieve abstract targets. This raises the question of the difficulty and meaning of ethical work for financial controllers.

The moral reputation of accounting professions (accountants, auditors, management controllers) has been undermined by governance scandals such as Enron, Worldcom, and Parmalat, together with the recent economic crisis (Atkinson, 2002; Rogers et al., 2005; 
Carnegie and Napier, 2010). Most professional bodies worldwide have reacted by implementing new codes of ethics that were soon criticised for associating virtue with mastered and codified techniques rather than with character and morals (Velayutham, 2003). Yet the contributions and limitations of professional codes of ethics and incentive systems (see for example Rosanas and Velilla, 2005) are not the main focus of this study. In this paper, what is considered unethical does not primarily concern infringing professional rules (e.g. "cooking the books") or partiality to certain stakeholders (e.g. favouring consumers' interest over shareholders' wealth). Rather, this article moves away from ethics in the sense of compliance with codes and moral reasoning and considers people's real life when confronted to ethical considerations in a working environment. Consequently, the article draws on a theoretical perspective - phenomenology — in which ethical and unethical actions are based on the study of the ways in which things of the world and life (phenomena) appear to us. Specifically, with Henry's phenomenology we wish to explore how too great an emphasis on abstract representations to the detriment of lived experience makes ethical work particularly difficult for management accountants.

Henry's work is rooted in Husserl's phenomenology. In his seminal work The Crisis of European Sciences and Transcendental Phenomenology (1936 translated 1970), Husserl argues that since the emergence of scientific knowledge, the everyday life-world that we perceive subjectively through the senses has gradually been replaced by a geometric and mathematical world. Consequently, knowledge and actions are no longer necessarily aimed at the world of real life, that is real praxis focusing on empirical reality, but rather at the pursuit of geometric shapes and mathematical formulae. Hummel (2006) has extended Husserl's critique beyond the scientific domain and argues that it is equally relevant in the field of 
management. The ubiquitous association of IT and financial concepts in modern organisations is a testament to the deep-rooted reliance on abstractions and limit shapes.

Henry's pioneering framework in phenomenology, and in western philosophy, is to distinguish two modes of appearing: intentionality (appearing of something in the world through representations) and affectivity (understood as the appearing of life). This distinction makes it possible to understand living subjects' morality and ethics as manifested in the "affective flesh" of people through a multiplicity of forms such as, for example, a renewed enthusiasm for pursuing their actions or, on the contrary, a mental and nervous breakdown when the immanent dynamic of their active and affective life is hindered. In turn, the immanent root of ethics may empower the living subject in a professional role to consent and follow codified charts, codes, standards, models and regulations (and sometimes to contribute to reformulating and improving them). In this paper, we wish to show the relevance of Henry's phenomenology of life to ethics in a context where work tasks may be limited to manipulating abstract, computerised representations. Consistent with Henry, we anchor ethics in a specific mode of appearing - the appearing of life - which goes beyond, without abolishing, ethical behaviour in relation to compliance with codes and guidelines advocated by professional bodies and legal authorities.

The Airshop case study illustrates the wide range of possible practices among individuals working as management accountants. Such practices are not particularly conducive to the flourishing of virtue in a working environment. Financial controllers' difficulties when seeking to act as moral individuals will be carefully analysed. The Airshop case is remarkable in that it encompasses a variety of work situations involving distant authority, machines, 
abstract objectives and repressed feelings, and demonstrates how living subjects find ways to work ethically in the role of financial controllers.

The remaining part of the article begins with a brief review of the literature on issues related to the work of management accountants and ethics. Secondly, a section introduces the article's theoretical framework - ethics of life - based on the works of the French phenomenologist Michel Henry (1922-2002). It is followed by an introduction to the research site and context and an in-depth analysis of the Airshop case study divided into two subsections, which describe individuals enacting their positions as management accountants behaving like "cogs in the machine" and as affected co-workers respectively. The discussion section contributes to a better understanding of the difficulty and meaning of ethical work for financial controllers and makes recommendations. Lastly, the conclusion summarises the findings.

\section{On management accounting and ethical concerns associated with financial reporting}

Since the beginning of the twentieth century, financial control departments and reporting practices have been central to large organisations requiring forecasting techniques and financial data to adjust demand and production, allocate scarce resources and assess the performance of decentralised business units on the basis of financial results (Fligstein, 1990). The 1970s saw the success of the financial conception of the firm among large American companies obsessed with shareholder value creation (Davis, 2005). This was soon theorised by agency theorists (e.g. Jensen and Meckling, 1976), who called for the implementation of mechanisms which could compensate for the information asymmetry in favour of operational managers when financial risks are borne by shareholders exposed to executives' opportunism. Financial control mechanisms designed to supervise those in management positions and make 
sure they safeguard distant shareholders' interests have since thrived. In this context, management accounting is a tool to control executives and make them accountable. It enables small centralised management teams to delegate operations without relinquishing control (Hopwood, 1987). Financial reporting is a language that makes experts' activities intelligible to non-experts (Armstrong, 2000).

Top executives are also frequently criticised for relying heavily on management accounting systems not primarily for managerial purposes but to communicate information to external audiences such as business analysts and investors with the hope of improving their company's share value (Pesqueux, 2003; Aglietta and Reberioux, 2005). This has dramatic unexpected consequences: the influence of "good" reporting figures on share value has been identified as one of the major causes of manipulations exemplified by scandals such as Enron, Worldcom and Parmalat. The solutions proposed to prevent similar scandals essentially involved tightening auditors' control over accounting reporting practices and providing moral guidance to business players. Ethical behaviour has since been defined at length in professional codes of conduct (for managers, accountants, auditors etc.), in laws (e.g. SOX in the USA, LSF in France) and in sets of best practices that largely ignore the question of individuals' personal experience and attitude toward ethical dilemmas (see Loeb and Cory 1989 for an exception).

The question of the ethical dilemma faced by individuals working as management accountants is central to this study. Some consider that the very discourse of accountability based on accounting practices is pervaded by neo-classical economics that force entities to pursue their own ends regardless of ethical considerations (e.g. Shearer, 2002). This vision is challenged by other research strands that show that there is no univocal use of management accounting. Macintosh (1995) demonstrates that management accountants are the interface of 
contradictory injunctions from headquarters and business units and are therefore key players in the dialectics of control when the conflicting interests of upper management and operational staff are resolved. Management accounting practices may thus support discussions in an interplay of antagonistic logics (social, financial, operational etc.) (Callon and Muniesa, 2004; Kalthoff, 2002, 2005; Quattrone and Hopper, 2005; Vollmer, 2007) that are sometimes reconciled (e.g. Quattrone and Hopper, 2006). Reconciling positions endorsed by different communities is an ethical challenge in itself (Pérezts et al., 2011). These different approaches overlook the fact that financial reporting technologies overemphasise abstract representation to the detriment of lived and affective experience (Faÿ et al., 2010). This paper refers to Henry's phenomenology to understand the impact of such an organisational contexts on ethics in the workplace. The question remains of how individuals working as management accountants in an environment saturated with apparati and abstractions can find a way to work ethically.

\section{An introduction to Henry's phenomenology of life, work and ethics}

We will now introduce Henry's phenomenology and its innovative contribution to challenge the so called "reality" of figures and abstract representations, and to shed new light on the ways in which human beings appear to themselves. It will then be argued that according to Henry, modes of appearing are the gateway to ontology (here, the ontology of the living being), and that ontology illuminates action, work and ethics. Lastly, an introduction to Gély's perspective of Henryan philosophy applied to social contexts in the workplace offers new ways to think about work and the ethics of work in organisational contexts.

Two modes of appearing: intentionality and affectivity 
Phenomenology raises the following question: how do phenomena appear to us? The radical novelty Henry (1973) introduces to western philosophy is to distinguish two modes of manifestation of phenomena: appearing "into the light of the world" and appearing "into the light of life." Appearing "into the light of the world" is the traditional mode for perceiving a phenomenon as exemplified by Husserl. In this case, knowledge is acquired through representations grounded in the intentionality of the perceiving subject who remains distant from the object. In western thought, work has long been understood through this mode of perception: what is considered is the visible product of work, the external characteristics of employment conditions. Knowledge of work is acquired through several measures based on conventions such as working hours, qualifications, wages and productivity. Management accountants are familiar with this mode of perception: they measure work according to these conventions and are able to make sense of variance when comparing their figures with budgeted expectations. The "light of the world" largely ignores the affective manifestation of work: the experience of making a painful or stimulating effort that appears through one's affectivity. Such experience is made through what everyone calls her or his life, says Henry: i.e. feeling good, enjoying life or feeling pain at work (the same applies, of course, to other areas of life). Henry refers to this second mode of appearing as "the light of life". It is important to note that all individuals cannot but be affected. Because there is no way one can distance oneself from one's affects, affectivity (the light of life) is permanent and inescapable. It is manifested through the whole range of affects from joy to pain, which everyone inevitably continuously experiences.

\section{From phenomenology of life to ontology}

Most importantly, Henry radically reverses the notion of what is "real." To him, affectivity gives access to reality without any need for mediation: 
"What is held to be real will (...) be whatever experiences itself immediately without being able to separate itself from itself (...) in short, what cannot be represented or understood in any way at all. What is real therefore is need, hunger, suffering, labour too - everything that consists in the inner and insurmountable experience of the self" (Henry, 1983, p.160).

Henry considers "real" experiences of life such as need, hunger, suffering, effort, as different from "objective" representations of realities. What is "real" is thus distinguished from “ideology," defined as:

"the whole of the representations of human consciousness in the sense of mere representations - the whole of the images, memories, ideas, notions, arguments, categories and theoretical or practical schemata that this very consciousness is capable of forming" (Henry, 1983, p.161).

Ideology doesn't always have a negative connotation for Henry: it is a necessary vehicle to allow reflexive thinking to happen and to enable effective social functional cooperation to satisfy life's needs. Yet Henry establishes a primacy of the light of life over the light of the world and locates what is real in life, not in representations. Taken seriously, this radical reversal has immense ethical consequences. When ideology refers solely to the world of representations, when it makes "as if" abstractions, measurements, and figures are not portrayed as resulting from the living efforts of working people but rather as having a life of their own, then ideology is perverted. Henry underlines that "barbarism" occurs when ideas and representations are no longer the language of affective life. In this case the eventually totalitarian negation of life in politics, economy or finance is never far away ${ }^{3}$. In short, abstractions may hinder the possibility of the appearance of life to guide working practices, thus blocking the pursuit of ethics. 
Following Henry's view of the potential duplicity of appearing we can now go a step further and note that there are two ways for people to obtain knowledge of her/himself. For Henry, prior to the representational "ego cogito" which provides an individual with the possibility to elaborate the story of her/his life in the light of the world, everyone is affected by her/his life immediately through affectivity. While we experience diverse affects, we also experience ourselves being affected. To Henry, the passive experience of being affected by oneself is the inescapable and immediate experience of one's life and therefore of one's self. Thus, in Henry's view, life is not an anonymous flow. Henry also stresses that nobody gives life to him/herself, and in turn everybody shares the common experience of being given life. Living life as a permanent gift is not the position of the isolated unethical self-centred ego, but the position of the one who receives and shares. Henry argues that being given life and self, all living individuals have the ability to seize and exercise (or not) all the powers of the body (to grasp, to open their eyes, but also to be affected, to talk, to listen, etc.) and of the mind (will, imagination, argument, etc.). Thus, individual life appears both as affective and active: empowered for action ${ }^{4}$. How do individuals move from passivity — being given life — to activity? According to Henry, in life there is an uninterrupted "coming" of given energy that everyone necessarily experiences when alive. Henry calls this "the law of our transcendental and absolute life" (2012, p. 100). It is impossible to flee from one's life; this is where "the durability of every need lies [...] its coming into oneself in the self growth of the absolute subjectivity of life" (2012, p.101). Work is of course one of several important places (as are the arts, religion, etc.) to deploy such energy.

\section{From ontology of the living being to work and ethics}

According to Henry, no one can escape the necessity of employing the energy received from life. He says that there are two ways to cope with this increased energy from growing life. The 
first possibility is to liberate this increased energy in action, deploying one's powers and abilities and thus offering one's life the opportunity to be lived to the full. The second possibility is to leave this energy unutilised, which will remain a terrible burden one yearns to escape from. This will also be true for work. For Henry, work is not an output that can be measured. In his view, work is another word for individual active life experiencing itself while the individuals endeavour to meet their needs and those of their loved ones. Such actions may (or may not) be an opportunity for growth according to life's prescriptions. Thus, fulfilling one's needs through the efforts of work may be 1) affected by the desire to live life to the full; or else 2) left unutilised by a self-centred ego worrying about representations for their own sake and looking for illusory images to be shown to others in the light of the world.

Henry names three areas where such desire and energy may be fulfilled: ethics, arts and religion. Thus, his conception of ethics offers a unique contribution by locating the nonintentional manifestation of ethical and non-ethical work in the light of life. In Henry's view, ethics is manifested through affectivity in the dynamic of one's active life and given energy to live life to the utmost. Affectivity gives access to what is real (oneself and others being affected by life) along with one's life desire, power and strength to act or work ethically. In the light of life, the ethical or unethical nature of actions appears through specific affects: joy and peace shared with others, or through unease, anomie, malaise and being shut off from others.

Experiencing malaise is not necessarily detrimental. Malaise and discomfort are intensifying the experience of life: increased energy is available. Malaise in itself can be the source of ethical actions in that it urges individuals to take a different course of action, to deploy their powers to act ethically and ground their action in life's requirements. Malaise is also an 
available energy for breaking with the position of the isolated ego and searching for creative ethical solutions with others, deploying with them the given energy of life through coordinated abilities in specific contexts. Thus, in Henry's perspective, looking for reasons for actions in representations (in the light of the world) or in their resulting impact will never give access to what is real. No metrics are conducive to ethical work because the desire and power to work ethically lies elsewhere than in the ego cogito: in affectivity experiencing energy received in life. This is why, following Henry, ethics is not rooted first and foremost in the light of the world, in intellectual considerations, or in codes or values.

\section{Investigating social contexts with Henry's phenomenology}

Despite the fact that Henry's work has been widely translated (into English, Spanish, Italian, Japanese, etc.), scant research in the field of organisation studies has drawn on his conceptual framework (see Uchiyama, 2003; Faÿ, 2005; 2007; Faÿ et al., 2010; Letiche 2006; Yoneyama, 2007 for exceptions). One must admit that applying Henry's concepts to empirical situations raises some epistemological questions. Philosophers such as Gély (2007) have successfully translated Henry's framework into issues of social relevance such as the configuration of roles in societies and organisations. Gély shows, for example, that uneasiness, anomie and malaise are triggered by stipulations for actions included in the role and dictated solely by concerns for matters that are ideologically disconnected from one's active and affective life (i.e. through abstract ratios such as efficiency, performance and optimal production). Gély also states that an individual's life is a whole series of powers (powers of the body and of the mind) given to one's affective and active life. Gély argues that the division of work within organisations is perilous because it separates the various powers. He underlines that renewed energy for ethical action is found in the conjunction of several individuals' powers, complementing each other and recognising the other - in its role - as 
another living human being, not as an obstacle, a means or an adversary. Gély provides the following interesting illustration: the power of talking given in life supposes someone exercising the power of listening and vice versa. Consequently, there is a risk of anomy for individuals in positions or roles that maintain people at a distance from each other. Thus, according to Gély, the configuration of roles is of great importance in the way it enables the powers and abilities of one's life to be developed in conjunction with others. Because they do not deploy the various powers of life, surveillance roles are explicitly likely to induce atrophy, malaise, and dissatisfaction (Henry, 2012, p.76). Acknowledging interdependences is a condition for the ethical actions of those deploying their active life through specific roles. When powers are shared, affection is a renewed drive towards cooperation.

In the next section, a case study will illustrate how individuals may react to that inescapable condition of being affected in different ways. We will illustrate how people working as management accountants live their working life, with many singularities. Specifically, we will answer the following questions: when performing a role of surveillance and control, how do managers experience the atrophy of their power? Being responsible for producing and manipulating abstract figures that are disconnected from the light of life, do they experience immense difficulties in working ethically? Given that the affective teleology of life is inescapable, how do some of the controllers find ways to accomplish ethical work given the configuration of their role?

\section{The Airshop case study}

Airshop is a company that specialises in the distribution of luxury products (mostly perfumes, alcohol and tobacco) at French airport terminals. From February to June 2004, 35 interviews 
were conducted with managers and financial controllers working either at the head office or at the airport. At the time of the study, Airshop had been using state-of-the-art software for its financial reporting activities for over two years. A highly centralised IT system provides managers at the headquarters with accounts for all the transactions occurring at more than 100 shops nationwide. By systematically comparing actual and forecast data, financial reporting has become a major component of the performance evaluation process for all managers. Management controllers, administrative directors, airport terminal managers, and sales managers examine the information circulating in the reports and compare actual results with the projected figures in the budget. This issue is of considerable importance: when actual performance is in line with the forecast, the employees receive financial bonuses, and when performance falls short of forecasts, management control is stepped up. The Airshop case illustrates the financial controllers' difficulties in playing their roles as mediators between operations and headquarters bound together by the circulation of abstract representations. The first subsection analyses the expectations and constraints associated with the management accountant's position, whereas the second analyses the different attitudes and reactions of individuals working as financial controllers.

\section{Management accountants as cogs in the reporting machine}

This subsection describes the Taylorist dimension of management accountants' work. Controllers are required to produce huge quantities of charts and figures to help executives make decisions. Stringent expectations about the quantity and quality of information are compounded by a lack of time to think, an inadequacy between figures and the reality of business and political power games that lead to figures being doctored. In such a situation, management accountants see themselves as crucial, but powerless, contributors to the reporting machinery designed for those in strategic positions. The metaphor of "cogs in the 
machine," i.e. playing a small but essential part in a mechanism bigger than themselves, seems an appropriate way to describe the way they affectively experience their work.

At Airshop, reporting processes have a rhythm of their own, orchestrated by the agenda of the monthly executive committee meetings and quarterly communications to financial markets. Management accountants contribute collectively to producing the reporting documents. To ensure effective tabulation of financial information, they exchange many emails and rely on shared databases; the circulation of reporting outputs is almost entirely digitised. Management accountants work on a virtual production line, keeping charts and figures moving from one workstation to another. The monitor is the work space where many contribute simultaneously to the collective production of shared financial templates.

"[Management accountants] have to wait for each other. If you are still at work at 11 pm, it means that 3 or 4 other people are still working too.” (Management accountant 7) Management accountants tend to work within walking distance of one another because they must talk to each other to be kept informed of the constant updating of information. Despite (and to some extent, because of) modern IT, financial people are concentrated at the headquarters. IT reinforces the links between colleagues from the financial control department and maintains geographical distance from operational managers based at distant airports.

"I work with all the other management accountants. We share the same tools, the same deadlines, the same concerns and therefore about $50 \%$ of our work is collective. [...] It is rather nice to be here [at the HQ] rather than at the airport, even if it means I definitely work less for the benefit of the operations." (Management accountant 1) The team efforts of management accountants are almost exclusively dedicated to drawing up Excel spreadsheets that are eventually sent to upper management. 
Innovation in IT has considerably improved management accountants' ability to compile large quantities of raw financial data. Yet demand for reporting documents has also greatly increased. Management controllers are overwhelmed by daily reporting duties and devote much of their attention to feeding the system. One controller, faced with a never-ending series of tasks, prefers to avoid contact with the operational staff to save time so he can cope with "the mass production of numbers" (management accountant 1). Another respondent hints at negative affects resulting from the situation:

"It is productivity above all. [...] You have neither the resources nor the time to go and see the people on-site and help them. I'm not even certain that we're currently exerting any actual control [over activities]. It's not a healthy situation.” (Management accountant 7)

The timing is tight and there is limited room for critical thinking. By highlighting economic objectives, management accounting pays little attention to the monitoring of actual practices (Armstrong, 1994). Formats and deadlines are more important than the actual content of the report because it is clear to all management accountants that only a tiny part of the data communicated will be considered in detail.

"When the reporting document is one inch thick, I'm not sure that everything will be read carefully.” (Management accountant 3)

Financial controllers are tempted to rely entirely on algorithms and technology. The quality of the final documents produced is assessed using formal coherence tests that ignore the on-site situation.

"[Reporting] is much faster than before but we spend less time checking the figures. We trust the software too much.” (Management accountant 5)

Management controllers also speak of their affect of uneasiness due to the gap between the representations of activities and the activities themselves. A notable example of this is in- 
flight retail activities, which are monitored in the same way as airport shops, despite major differences in consumers' preferences and attitudes in the two situations.

"We are required to stick to the reporting standards imposed by [the headquarters] and they are biased because they are irrelevant to [our in-flight activity]. [...] There is a gap between what [the HQ] asks for and what we are.” (Management accountant 7)

Accounting is a process of standardisation (Townley 1995, p.561): using a common unit (money), it unites disparate elements. Thus despite discrepancies between the reality of operations and the figures communicated to senior management, people have no other choice but to keep referring to the official reporting measures when dealing with superiors.

Because operational managers know that the hierarchy assess the quality of their work based on reporting figures, many of them become caught up in political games. At Airshop, the constant reference to budgeted figures used as objectives to assess individual performance has given rise to subtle tweaking of forecast calculations. All the interviews highlight that targets are subjected to arbitrary adjustments, either upwards or downwards, which have nothing to do with operational considerations. Estimates made by operational managers regarding future trends may be followed by numerous discussions behind closed doors during which top management reserves the right to stipulate increases to selected numbers. It is not uncommon for managers to discover that their forecasts have been revised without their being informed. Management accountant are consequently isolated from managers.

"When we make the adjustments to a BU's budgets we don't get in touch with the operational managers concerned." (Management accountant 8)

Top-down adjustments blur the relationship between the figures and the elements they were originally based upon: political decisions at top management level disconnect numbers from 
operational situations and render them meaningless. Last-minute changes negatively affect management accountants and destroy the feeling of contributing to a meaningful work.

"When there is a top-down order to cut the wage bill by $€ 150,000$, either you have the time to deal with it on a case-by-case basis (that never happens), or you enter 300 instead of 450 and are bothered all year long with variations calculated based on foolish objective." (Management accountant 7)

All possible means are used to project a good image of oneself to distant superiors. The most common practice is the doctoring of performance measures using financial reserves (accruals) or the latitude offered by diverse accounting rules. Management accountants are involved in such discussions.

"We have a look at the reporting of the different BUs in comparison to the budget and we decide to make a few adjustments regarding accruals for example. [...] What is communicated to [the parent company] includes the adjustment in order to spread actual costs or anticipate future ones. Our objective is to stay close to the budget figures." (Management accountant 4)

The negotiations on figures between corporate and operational managers show that the demand for consistent accounts has consequences that are not conducive to responsible behaviour (Ezzamel et al., 2008). Management accountants manipulate the performance targets set between corporate managers and operational managers: budgeting and reporting is a game in which they play an active role. Most of the time, they do not feel comfortable about playing with figures and do so reluctantly, notably because of the damaging effect it has on the atmosphere between the company's entities as exemplified in the following quote.

"There is some sort of a game with the headquarters who look down on [operational managers] and [the latter] claim that the headquarters don't understand anything. There 
is a defiant atmosphere between the headquarters and the subsidiary." (Management accountant 7)

There is therefore a focus on playing with numbers, at the expense of management-related issues. The image of reporting as a game is widespread and manipulations are considered "unhealthy" (management controller 1). The real experience of work is overlooked while its representations are the dominant concern; this is affectively experienced by the interviewees. Indeed, very little information about what actually happens in operational situations is communicated to top management.

\section{Affectivity and the difficulties of ethical action: when to throw a spanner in the works?}

This sub-section illustrates how many management accountants involved in financial reporting practices find it difficult to feel comfortable with their actions at work. It focuses on the dilemma of whether or not they should take their affectivity into account in decision making. The strategies managers apply to ignore malaise-inducing situations at work include distancing themselves from others and focusing all their attention on technical accounting issues, timing and forecast precision. Others, in contrast, bridge the distance between people and allow themselves to be affected by the joys and pains of daily actions, and direct their efforts towards ethical responses in complex working environments. Invariably, a central issue is to find the confidence to stop being a mere cog in the machine and act, on some occasions, as spanners in the works of abstract management. ${ }^{5}$

Management accountants' reactions when confronted with situations where figures are manipulated are diverse: it is not uncommon to hear signs of resignation when management accountants consider that their behaviour is dictated by considerations beyond their control. Coldness and distance become a refuge from thoughts and feelings. 
“Sometimes I'm told to bring the forecast up to a point, which I don't agree with, but I do it all the same." (Management accountant 1)

"Sometimes I prepare something for the budget and they do things differently, and sometimes I don't agree and in that case I become very detached from what I've done”. (Management accountant 5)

When management accountants occupy intermediate positions in the hierarchy, they can avoid being involved in unpleasant political games by assigning these tasks to subordinates.

"As far as financial reporting is concerned, I know I should not have done it but I got someone else to do it because I was so fed up with it!” (Management accountant 7)

Delegating the job to others enables some controllers to escape from the unease arising from tasks that have lost all meaning and relevance. Further, while none of the management accountants interviewed was satisfied with the lack of human interaction in reporting exercises, it is also a way for those who cannot escape the duty of reporting to avoid being directly confronted with other people's dissatisfaction with the figures.

Management accountants also willingly take refuge in the exactness of abstraction, in the formal beauty of formulae, and the flawless logic of coherent forecasts to evaluate the quality of their job and take pride in achievements. Satisfaction derives from the coherence of the model and the accuracy of forecasts.

"A good forecast is when you have a clear vision of the accounts, bills and coming sales and you smooth them over the months to avoid any unexpected jumps in figures." (Management accountant 4)

Management accountant 6 considers that an important aspect of their job is "to get proper accurate forecasts." Meeting deadlines and anticipating executives' expectations are also 
significant quality criteria for management accountants' work. Anticipating questions from upper management provides satisfaction.

"During the budgeting process the most important thing is to be on time. We were very late last time and it created tensions. We didn't do a good job at all because we sent the information to [the parent company] too late. The other criterion for the quality of reporting is not to have the CFO changing 25 items in your document. This is not a good sign at all.” (Management accountant 8)

When management accountants overcome the difficulties of handling vast quantities of data and producing a report within a limited timeframe, they take pride in their technical and organisational achievement. The ability to conduct the reporting project again and again can become more important in the eyes of financial controllers than its actual content, over which they have less control.

Yet the same management accountants also consider that a large part of the enjoyment of work comes from interacting with other employees who express an interest in the report. Such rewarding experiences rely heavily on the attitudes of operational people who may or may not pay attention to the job done by their financial controllers.

"My relationship varies from one category of manager to another. [P] is very involved and he really pays attention [to figures]. [B] is not so concerned. To me, it's much nicer to work with $[\mathrm{P}]$ on the margins and the detailed studies he regularly requests of me. I definitely get less work from [B] but I also feel I am not very useful to her." (Management accountant 8)

Operational managers who engage in discussions with controllers learn about the close relationships between their activities and those carried out at headquarters. In several cases, financial targets and objectives are regularly compared with local business factors; singular 
local events often supersede the targets. Frequent discussions maintain a link between practices and reporting, thereby providing all managers with a better understanding of situations.

"When I work on the weekly sales figures I call [the terminal manager] to find out why they are so good, or so low. [...] They know about the strike of such and such category of staff whereas I would not be aware of any of that on my own. It makes a huge difference.” (Management accountant 8)

Reporting figures may thus support face-to-face encounters and direct phone contact that are consistent with a "socialising" type of accountability that cultivates dialogue (Roberts, 2001; 2003). Questions and ideas raised by reporting figures can be starting points for discussions with operational managers.

"Forecasts are a good opportunity to understand what is happening locally. We are currently seeing a drop in the SPP ratio. We have to understand the causes of this major concern. Why are we lagging behind the budget? Why did we get it wrong? What can we do to get back on track?” (Management accountant 1)

Management accountants have a chance to acquire new knowledge by interacting with operational managers. They may even experience new skills that help them make sense of peripheral activities. Their work may be a chance to develop virtuous cooperation: colleagues willing to meet and share the difficulties of their job are likely to ignore, at least temporarily, the pressure from the ideology embedded in the software. Joint efforts allow management controllers to experience the reality of operational managers.

"I work directly with the operational managers. It's a team effort and we rely on one another a great deal [...] I try to go to the airport once a month to visit the shops, give them a hand setting up. Next Tuesday a remodelled shop is opening, so everyone's 
coming to lend a hand moving, which will be a good way of getting to know everyone as well as the sales outlet." (Management accountant 1)

Not all management accountants blindly apply upper management policies. Some are even considered "renegades" by operational managers who appreciate the fact that they remain critical of injunctions from upper management. Because management accountants have access to executives at headquarters, they are precious allies for certain operational managers in voicing their arguments. Management accounting distributes economic calculations throughout the organization, yet does not reduce everything to economics.

"I try to implement the parent company's procedures as much as possible, up to the point where I must say 'no, it's really not appropriate to impose that'.” (Management accountant 7).

"[The software] is important but it's not a substitute for a management accounting department because our activities have the limitations inherent in fully automated control. For example, we can have instant access and compile all sorts of data because the software is very powerful but it won't do ad hoc studies or understand the differences between product categories. There are limitations to mathematical reasoning.” (Management accountant 9)

Numerous managerial positions are largely mediated by IT in their relations to operations. Managers therefore choose, at many hierarchical levels, to ignore the malaise of being separated from reality by constantly referring to abstractions or, on the contrary, using reporting as an opportunity to work more closely with other people. There are restrictions on the second option because of the deadlines and the lack of immediate rewards for this open attitude. Yet there is also the potential satisfaction of a collective feeling of real achievement, which is a far cry from impersonal, distant and abstract management. 


\section{Discussion}

The Airshop case study presented above shows a remarkable variety of accounts of the situation at the company given by management controllers. We will now discuss the fact that several of them try to flee from their affectivity through detachment or by focusing all their attention on the beauty of figures and representations, while others say "no", voice operational managers' arguments, and/or maintain a critical attitude towards reporting tools.

\section{Managing through abstract representations}

In the prologue to this paper, managers at Airshop's headquarters receive abstract representations of operations through the mediation of IT and management accountants' work. In Henry's terminology they have a "theoretical" (etymologically "a world vision") perception of business operations. "Visualisation" enables managers at Airshop's headquarters to run their company from their offices and learn about remote points of sale through figures based on financial data: they may manage others while sitting at their desk and clicking on icons, their eyes and minds focusing on formulae and computer interface. Here, work done on the shop floor is made visible using SPP ratios but it is not experienced. Senses other than vision are not considered legitimate means of gaining knowledge because managers and accountants inhabit, think, and live in a world of papers and screens. They know the world essentially by way of ideal representations and abstract models. Following the accident at terminal 2E, it became clear that other employees' efforts and activities are invisible to managers who rely extensively on financial ratios to manage the organisation. Each person's relationship to the world is complex, combining simultaneously ideology/representations and reality/affectivity: the two modes of appearing are complementary. Reflexive thinking requires the support of abstract concepts, and no one can 
escape the reality of lived experience. Yet the two modes of perception are not of equal value. Henry insists on the primacy of affectivity; ideology is not independent from lived experience because it is primarily determined by individuals' actual practices. The reverse is not true; ambition that aims to modify reality by changing the representations of this reality can be nothing but illusory (Henry, 1983). It leads to political games illustrated by forecast tampering at Airshop that causes discomfort among management accountants.

\section{The difficulty and meaning of ethical work for management accountants}

In recent decades, Actor-Network Theory has convinced researchers not to separate the study of humans from that of artefacts (Latour, 1987). Tools, technologies and formulae belong to the vast population of "actants" (i.e. human and non-human actors) which have an impact on most human activities. From a phenomenological point of view, the intermingling of humans and non-humans creates a hybrid perception, considerably increasing or decreasing the abilities of our senses. Management accountants rely on specific, dedicated equipment, in particular financial software, which keeps them at a distance and captures their attention. Software and computers greatly increase users' memory, vision and calculation abilities. Managers using reporting IT tools do not experience the business the same way as the workers on site. Henry's phenomenology highlights the consequences on ethical behaviour of the dominance of visual and distant perception over consideration for the affective experience of work situations. Financial representations are mere representations of activities that take place elsewhere in organisations and it is these activities that produce growth, values, products and services. In situations where individuals are separated from reality by an apparatus that favours abstract concepts over lived experience, social ties are undermined. The management accountants who succeed in anchoring figures in operational practices are those who maintain close ties with other managers, visiting them on sites and engaging in 
regular interactions. It is by striving to situate representations within the reality of working practices that forms of malaise can be overcome and new strength gathered to favour ethical collective collaboration.

The Airshop case shows that the role of management accountants may be performed in different ways. On several occasions the management accountants' testimonies evoke their difficulties appreciating a job that is often limited to the rigorous and consistent compiling of figures into charts. All controllers refer to the lack of time for reflection, the pressure to make accurate forecasts and the focus on delivering adequate numbers to remote colleagues. However, the way individuals play their part as management accountants is not entirely determined by the tasks and responsibilities stated in their job descriptions. Following Gély, individuals in the role of financial controllers give life to different "characters". Being a management accountant is thus an opportunity to interact with other individuals in positions of top executives or sales managers. More importantly, these collaborations require individuals to go beyond their mere job description and creatively face the difficulties of the tasks at hand. A major source of satisfaction is, for example, when management accountants help their colleagues at points of sale to make themselves heard at upper management level. A necessary prerequisite for such an enjoyable, ethical outcome is that each individual recognise other people's roles as complementary.

"The powers I have are never such a living force as when they are connected to other people's powers. When applied to roles, this theory means that individuals are vitally concerned by the way other people handle them.” (Gély, 2007 p.90-91)

It is in this combination of the powers of different roles that individuals pragmatically experience ethical work. Affective conjunction of living individuals is experienced in face-to- 
face cooperation and complements functional cooperation. When others are not mere means but living beings, the desire to achieve goals together is renewed.

“One's life forces are magnified when they are shared. Concern for another person's life requires living interaction with them.” (Gély, 2007 p.196)

Even roles involving surveillance, such as being a financial controller in charge of evaluating other peoples' performance, affords opportunities to make contact with individuals with whom one can share and combine complementary powers. A number of roles offer opportunities to face and overcome challenges jointly, through cooperation. Although it may not be explicitly mentioned in job descriptions, most positions involve regular contact between people, explanations and the curiosity to get to know the others' concerns. Talking, listening and acting collectively express the conjunction of powers and sharing of a common life. Jobs are also a way to get to know other people better and experience the pleasure and dynamism of collective cooperation.

This article complements the few existing studies on the conditions required for managers to be truly ethical. Townley (2004), for example, relies on Gowler and Legge's distinction between management as a technical and scientific order and management as a moral order (1983) to address how managers deal with various strategies. She notably considers the possible managerial strategies, some of which have strong ethical implications and are characterised by a humanist appeal to social values to guide action, while others are described as adherence to technology and results, and a focus on getting the job done. Yet Townley does not consider the question of the origin of ethical values which Henry grounds in the inescapable auto-affection of one's life. The fact that several financial controllers try to balance the affective uneasiness with the pleasure of refining abstract figures cannot remove their immediate experience of a praxis disconnected from life's needs and prescriptions. The 
energy dedicated to pursuing ideological objectives taken from models and representations is a solitary ego's attempt to flee from life's imperatives. Nonetheless, by seeking to enact their power in conjunction with others, on the contrary, management accountants find viable solutions. The increased energy in their active life lets some financial controllers muster the strength to act according to practical wisdom. They say "no" to ideologically driven decisions, are able to voice operational managers' arguments and take a critical, reflexive distance from abstract representations. Such experiences are manifestations of growth characterised by the transition from suffering (malaise) to joy. In Henry's phenomenology, suffering takes on a novel and unexpected meaning, that of absolute life disturbing and helping the self: "This [experience of growth] can never be dissociated from the eternal process in which the Absolute [life] comes into oneself and is historicised" (2012, p. 101) .

\section{Recommendations to management accountants}

In this section we formulate some recommendations for management accountants based of the Airshop experience. It is crucial for management accountants not to deem their job to be successfully completed merely when figures are consistent and satisfactory to top management. Focusing on formal coherence and political arrangements over critical affective assessment of situations may be an easy option, but it is detrimental to both the organisation and to the possibility of fulfilment at work. This attitude can lead to the ignoring of the resulting malaise when distorting reality to favour abstractions over lived experience or satisfy unrealistic, virtual expectations. Malaise, unrest, uneasiness etc. are important signs that should force financial controllers to question their own practices. If affectivity is ignored or negated in the pursuit of formal compliance, it may well result in organisational anomie and profound dissatisfaction with one's work. 


\section{Conclusion}

This article has documented some of the virtuous and unethical ways in which management accountants work using IT for reporting and control. It confirms that such systems can be powerful instruments to enforce a form of surveillance and discipline that prevents open dialogue or, on the contrary, can serve as a learning and coordination device (Free, 2008). The case study relies on Henry's phenomenology to distinguish between two modes of appearing: the remote and abstract representations (subjects represent themselves as distinct objects seen at a distance in the "light of the world") and the reality of affectivity through which every subject undoubtedly never ceases to experience him/herself with no distance in the "light of life." To some extent, it shows that people working at Airshop's headquarters are members of a disembodied corporation governed at the top by abstract objectives and managed via electronic interfaces. Such an organisation prevents discussion and mutual understanding. Yet the diversity of the situations reported by the Airshop employees stresses that the complexity of working relations cannot be explained entirely by the distance imposed by representations and technical interfaces. Many management accountants try to ease the tensions raised by managerial practices that encourage distant managers to make demands and expectations requiring extra efforts, regardless of the operational context. They make particular efforts to meet co-workers and have regular face-to-face discussions of the interpretations of abstract representations or explicitly voice their disapproval of representations that are removed from the surrounding lived experiences and that highlight the limits of reporting ideologies. The case study has helped us understand the problems inherent in jobs that make ethical behaviour difficult. Such difficulties give rise to strategies that managers apply fruitlessly to escape malaise, such as avoiding face-to-face encounters, attributing responsibility to absent others, and ignoring one's affective life by hiding behind screens and procedural agreements. 
Following Henry, the article argues that the pursuit of abstract objectives (in line with job requirements and technologies), regardless of the affective immanent and embodied ethical injunctions the subject may experience, is typically unethical behaviour. Ignoring malaise by cultivating distance from one's production, by focusing only on the abstract beauty and coherence of figures while ignoring others' experience, is unethical. Henry's ethics is rooted in a teleology of life that is radically opposed to the pursuit of abstract objectives for the sake of disembodied and affectless entities (the shareholders, bosses, markets, etc.). Specifically, Henry's phenomenology illustrates how people at work may deliberately ignore their own and other people's affects or, on the contrary, agree to be affected and virtuously amend their behaviour accordingly.

We do not claim to have explored every aspect of Henry's phenomenology. Interestingly, Seyler (2010: 214) develops the epistemological argument that phenomenological discourse has an indicative function towards affective life, and that limitations on such discourse call for the primacy of practice. Substantial contributions are still needed to study further Henry's phenomenology of life and its contribution to the field of ethics, notably by distinguishing and articulating concepts such as immanence and transcendence, passivity and activity. It was also beyond the scope of this paper to compare Henry's non-intentional phenomenology with that of Levinas, which has already inspired numerous scholars in the field of business ethics (e.g. Bevan and Corvellec, 2007; Jones, 2007; Muhr, 2009; Baker and Roberts, 2011). Lastly, we have not referred here to Henry's study of Christianity (2002) which expands the grounding and meaning of ethics. Accordingly, Henry argues that the fulfilment of desire in actions reveals not only the achievement of good life but also the appearing of Life/God in human action. Further inquiries into the foundations of ethics at work may also build on Henry's 
argument, derived from this phenomenology of Christianity, of an immediately given affective sense of brotherhood/sisterhood that could be very useful to describe or prescribe more ethical human relations in the workplace. 
Appendix: Schedule of formal interviews at Airshop

1) April 2004 Treasurer

2) April 2004Management accountant 1

3) April 2004 Management accountant 2 (head of department)

4) April 2004Management accountant 3

5) April 2004Management accountant 4

6) April $2004 \mathrm{Head}$ of Accounting department

7) April 2004Management accountant 5

8) April 2004Management accountant 6

9) April 2004Buyer 1

10) April 2004Buyer 2

11) April 2004Category Manager

12) April 2004Head of Subsidiary

13) April 2004Buyer 3

14) April 2004 Management accountant 7

15) April 2004Management accountant 2

16) April 2004 Management accountant 8

17) May 2004Category Manager

18) May 2004Operational Manager 1

19) May 2004 Operational Manager 2

20) May 2004 Operational Manager 3

21) May 2004 Supply Chain Manager

22) May 2004 Operational Manager 4

23) May 2004 Buyer 4

24) May 2004 Category Manager

25) May 2004 Buyer 5

26) May 2004 Head of Human Resource department

27) May 2004 IT Manager

28) May 2004 Management accountant 9

29) May 2004 Operational manager 5

30) May 2004 Operational manager 6

31) May 2004 Vice-President

32) May 2004 IT Director

33) May 2004 Operational manager 7

34) June 2004Chief Financial Officer

35) June 2004Chief Executive Officer

All the people interviewed agreed to be quoted in academic publications (with the understanding that their names would not be mentioned). 
${ }^{1}$ Airshop is a fictitious name of a company where one of the authors conducted a three-month field study of the role of management accountants in the governance of subsidiaries.

${ }^{2}$ In this article, "management accountant" (MA) and "financial controller" are used interchangeably. Both refer to a job position primarily concerned with the production of financial information for managerial purposes (e.g. budgets, forecasts, reporting).

"Management accountant" and "financial controller" are the two usual translations of the French term "contrôleur de gestion."

${ }^{3}$ We are grateful to the anonymous reviewer who pointed out the subtlety of Henry's attitude regarding ideology to us.

${ }^{4}$ Acknowledging that affectivity illuminates the reality of the phenomenon and that affectivity is intimately related to the manifestation, in one's life of ethics, presupposes an education that allows discernment of various affects: affects of a self-centred ego or affects of an open ego may be distinguished according to real effects in life with and for others. One is thus able to experience affectively whether the exercise of one's powers, gifts and abilities is good or bad for life according to some experienced laws of life: i.e. there is more joy in giving than receiving. Such a law is consistent with the acknowledgment of living a given life.

${ }^{5}$ The spanner trope reputedly derives from the industrial revolution-era practice of workers sabotaging machines in an attempt to improve working conditions.

${ }^{6}$ There are different ways to account for the links between absolute Life and everybody's life, depending on cultures and religious traditions: see Yoneyama with Zen Buddhism (2007) and Letiche (2009) with non-transcendent humanism. 


\section{References}

Aglietta, M. \& Reberioux, A. (2005). Corporate governance adrift. Cheltenham: Edward Elgar.

Armstrong, P. (1994). The influence of Michel Foucault on accounting research. Critical Perspectives on Accounting, 5(1), 25-55.

Armstrong, P. (2000). Designing accountability: the managerial semiotic project. Critical Perspectives on Accounting, 11, 1-22.

Atkinson, A. S. (2002). Ethics in financial reporting and the corporate communication professional. Corporate communication, 7(4), 212-218.

Baker, M., Roberts, J. (2011). All in the Mind? Ethical Identity and the Allure of Corporate Responsibility. Journal of Business Ethics, 101: 5-15.

Bevan, D. and Corvellec, H. (2007). The Impossibility of Corporate Ethics: For a Levinasian Approach to Management Ethics. Business Ethics: A European Review, 16(3): 208219.

Boland, R. J. (1987). The in-formation of information systems. In R. J. Boland \& R. Hirschheim (Eds.) Critical Issues in Information Systems. New York: John Wiley and Sons.

Callon, M., \& Muniesa, F. (2004). Les marchés économiques comme dispositifs collectifs de calcul. Réseaux, 21(122), 189-233.

Carnegie, G. D., \& Napier, C. J. (2010). Traditional accountants and business professionals: Portraying the accounting profession after Enron. Accounting Organizations and Society, 35, 360-376.

Davis, G. F. (2005). New directions in corporate governance. Annual Review of Sociology, 31, 143-162. 
Ezzamel, M., H. Willmott, F. Worthington. (2008). Manufacturing shareholder value: The role of accounting in organizational transformation. Accounting Organizations and Society (33), 107-140.

Faÿ, E. (2005). Life, speech and reason: A phenomenology of open deliberation in organization. Ephemera, 5, 472-498.

Faÿ, E. (2007). A critical and phenomenological genealogy of the question of the real in Western economics and management. Society and Business Review, 2. 193-203.

Faÿ, E., Introna, L., Puyou, F.-R. (2010). Living with numbers: Accounting for the subjectivity in/with management accounting systems. Information and Organization, 20, 21-43.

Fligstein, N. (1990). The transformation of corporate control. Cambridge, Massachusetts: Harvard University Press.

Free, C. (2008). Walking the talk? Supply chain accounting and trust among UK supermarkets and suppliers. Accounting Organizations and Society, 33, 629-662.

Gély, R. (2007) Rôles, action sociale et vie subjective. Recherches à partir de la phénoménologie de Michel Henry. Brussels: Peter Lang.

Gowler, D., \& Legge, K. (1983). The meaning of management and the management of meaning a view from social anthropology. In M. Earl (Ed.), Perspectives on Management: A Multidisciplinary Analysis. Oxford: Oxford University Press.

Hancock, P. (2008) “An Ethics of Organization and Embodied Generosity”, Organization Studies, 29(10), 1357-1373

Henry, M. (1973). The Essence of Manifestation (G. Etzkorn, Trans.). The Hague: Nijhoff.

Henry, M. (1983). Marx. A Philosophy of Human Reality (K. McLaughlin trans.). Bloomington: Indiana University Press. 
Henry, M. (1999). Material phenomenology and language. Continental Philosophy Review, 32, 343-365.

Henry, M. (2002). I am the Truth: Toward a Philosophy of Christianity (S. Emanuel trans.). Stanford University Press.

Henry, M. (2012). Barbarism (S. Davidson, Trans.). London \& New York: Continuum.

Hopwood, A. G. (1987). The Archeology of accounting systems. Accounting Organization and Society, 12(3), 207-234.

Husserl, E. (1970). The Crisis of European Sciences and Transcendental Phenomenology. Evanston, Illinois: Northwerstern University Press.

Hummel, R. P., (2006). The Triumph of Numbers: Knowledges and the Mismeasure of Management. Administration \& Society. 38 (1), 58-78.

Introna, L., \& Ihlarco, F. M. (2004). The ontological screening of contemporary life: A phenomenological analysis of screens. European Journal of Information Systems (13:3), 221-234.

Letiche, H. (2009). Reflexivity and Affectivity. Culture and Organization (15:3-4), 291-306.

Loeb, S. E. \& Cory, S. N. (1989). Whistleblowing and management accounting: An approach. Journal of Business Ethics (8), 903-916.

Jensen, M. C., \& Meckling, W. H. (1976). Theory of the firm: Managerial behavior, agency costs and ownership structure. Journal of Financial Economics (3).

Jones, C. (2007). Editorial Introduction. Business Ethics: A European Review, 16(3): 196-202.

Kalthoff, H. (2002). Figures, writing and calculation: Thoughts on the representation of economic practice [Electronic Version]. Economic Sociology, European Economic Newsletter, 3, 28-39.

Kalthoff, H. (2005). Practices of calculation. Economic representation and risk management. Theory, Culture and Society, 22(2), 69-97. 
Knights, D. \& O’Leary, M. (2006). Leadership, Ethics and Responsibility to the Other, Journal of Business Ethics, 67, 125-137

Latour, B. (1987). Science in Action. Harvard University Press, Cambridge, Massachusetts.

Loacker, B., Muhr, S.L. (2009). How Can I Become a Responsible Subject? Towards a Practice-Based Ethics of Responsiveness. Journal of Business Ethics, 90: 265-277.

Macintosh, N. B. (1995). The ethics of profit manipulations: a dialectic of control analysis. Critical Perspectives on Accounting, 6, 289-315.

Pérezts, M., Bouilloud, J.-P., \& de Gaulejac, V. (2011). Serving two masters: The contradictory organization as an ethical challenge for managerial responsibility. Journal of Business Ethics, 101(extra 1).

Pesqueux, Y. (2003). Corporate governance and accounting systems: a critical perspective. Critical Perspectives on Accounting, 16(6), 797-823.

Quattrone, P., \& Hopper, T. (2005). A ‘time-space odyssey': management control systems in two multinational organisations. Accounting, Organizations and Society, 30(7-8), 735764.

Quattrone, P., \& Hopper, T. (2006). What is IT?: SAP, accounting, and visibility in a multinational organisation. Information and Organization, 16(3), 212-250.

Roberts, J. (2001). Corporate governance and the ethics of narcissus. Business Ethics Quarterly 11(1), 109-125.

Roberts, J. (2003). The manufacture of corporate social responsibility; constructing corporate sensibility. Organization 10(2), 249-265.

Roberts, J. (2009). No one is perfect: the limits of transparency and an ethic for 'intelligent' accountability. Accounting Organizations and Society (34), 957-970.

Rogers, R. K., Dillard, J. \& Yuthas, K. (2005). The accounting profession: Substantive change and/or image management. Journal of Business Ethics (58), 159-176. 
Rosanas, J. M. \& Velilla, M. (2005). The ethics of management control systems: Developing technical and moral values. Journal of Business Ethics, (57), 83-96.

Sanders, P. (1982). Phenomenology: A New Way of Viewing Organ ${ }^{\mathrm{iz}}$ ational Research, The Academy of Management Review, 7(3), 353-360.

Seyler, F. (2010). Barbarie ou culture. L'éthique de l'affectivité dans la phénoménologie de Michel Henry. Paris: Kime.

Shearer, T. (2002). Ethics and accountability: from the for-itself to the for-the-other. Accounting Organizations and Society, 27, 541-573.

Townley, B. (1995). Managing by numbers: accounting, personnel management and the creation of a mathesis. Critical Perspectives on Accounting (6), 555-575.

Townley, B. (2002). Managing with Modernity. Organization, 9(4), 549-564.

Townley, B. (2004). Managerial technologies, ethics and managing. Journal of Management Studies, 41(3), 425-445.

Uchiyama, K.(2003). The Theory and Practice of Actuality. Daito Bunka University Press, Tokyo.

Velayutham, S. (2003). The accounting profession's code of ethics: is it a code of ethics or a code of quality assurance. Critical Perspectives on Accounting, 14, 483-503.

Vollmer, H. (2007). How to do more with numbers. Elementary stakes, framing, keying, and the three dimensional character of numerical signs. Accounting Organizations and Society, 32(6), 577-600.

Yoneyama, E. (2007). Phenomenology of Life, Zen and Management. Society and Business Review2 (2), 204-217. 